レーザーオリジナル

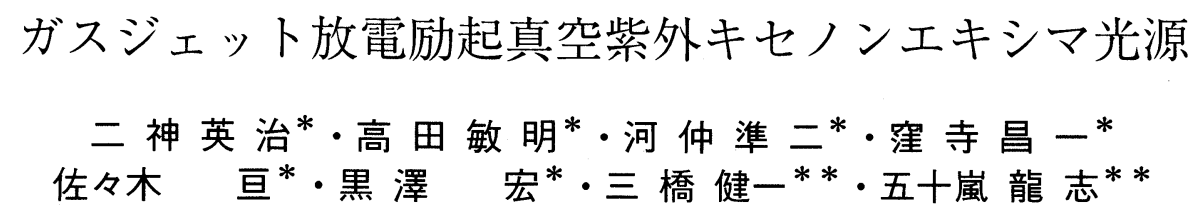

(1995年3月13日 受理)

\title{
Vacuum Ultraviolet Xenon Excimer Light Source Excited by a Pulsed Jet Discharge
}

\begin{abstract}
Eiji FUTAGAMI* , Toshiaki TAKADA* , Junji KAWANAKA*, Shoichi KUBODERA*, Wataru SASAKI ${ }^{*}$, Kou KUROSAWA ${ }^{*}$, Kenichi MITSUHASHI** ${ }^{*}$ and Tatsushi IGARASHI**
\end{abstract}

(Received March 13, 1995)

We have developed a new xenon excimer light source in vacuum ultraviolet (VUV). The use of a pulsed gas jet discharge realized efficient cluster excitation and spatially localized emission in VUV with an extremely long pulse duration. An output power of $1.5 \mathrm{~W}$ was obtained with a pulse width of $5 \mathrm{~ms}$ at $176 \mathrm{~nm}$, corresponding to an efficiency of $3.0 \%$.

Key Words: Rare gas excimers, Vacuum ultraviolet, Excimer lamp, Pulsed gas jet, Gas jet discharge

\section{1. はじめに}

近年, 材料科学, 物質工学から光化学, 分光 といった多岐にわたる応用分野において短波長 光源の要請が増加している。特に, リソグラ フィーに代表される極微細加工，低温·低損傷 処理, 高エネルギー光子による直接プロセス等 のマテリアルプロセッシングの分野において は, 従来とは全く異なる機構によりこれらを実 現するものとして, 真空紫外域(波長 $100 \mathrm{~nm}$ $200 \mathrm{~nm})$ での高出力光源の開発が期待されてい る1)。希ガスエキシマ(アルゴン, クリプトン,
キセノン)はこの真空紫外域において効率よく 光を放出する数少ない媒質のひとつであり, こ れまで高出力レーザー発振についての研究が行 われてきている2)。しかしながら, 希ガスエキ シマレーザーの発振には高圧力動作が不可欠で あり，それに伴い大規模な電子ビーム励起が必 要となる。このことは, 将来における種々の応 用に対する真空紫外域の光子のコストを考える 場合には大きな制限要因になると考えられる。 このため, 電子ビーム励起法を用いずに希ガス エキシマを生成するための新しい励起方法とし て，パルスガスジェットを用いた放電励起法が

*宮崎大学工学部電気電子工学科( $=889-21$ 宮崎県宮崎市学園木花台西1-1)

**ウシオ電機株式会社技術研究所( $=$ 671-02 兵庫県姫路市別所町佐土1194)

*Department of Electrical and Electronic Engineering, Miyazaki University, (1-1 Gakuen Kibanadai Nishi,

Miyazaki 889-21)

** Research and Development, USHIO INC. (1194 Sazuchi, Bessho-cho, Himeji, Hyogo 671-02) 
近年注目されている゙〜5)。

我々は，パルスジェットを用いて希ガスクラ ス夕を生成し，これを電子衝突励起することに より希ガスエキシマを生成する方法を提案して いる6)。ジェットノズルを通して真空中に希ガ スを超音速で噴出することで, 断熱膨張により 希ガスクラスタが生成される。この希ガスクラ スタを放電励起することにより, 希ガスエキシ マが高効率で生成される。この方法では, エキ シマの生成機構においてクラス夕の直接電子衝 突励起が支配的であるので, 従来の三体衝突を 介した励起生成機構と比べて低気圧下で効率の よいエキシマ生成が可能となる。従って, 低圧 動作による装置の小型化, また放電励起に伴う 高繰り返し動作が可能となり, 高出力動作が可 能な大型の電子ビーム励起法と相補的な励起方 法として重要である。加えて,パルスガスジェッ 卜の使用により，希ガス媒質を空間的，時間的 ともに局在した状態で励起することができるこ とから, 従来にない任意の発光形状を持つ真空 紫外希ガスエキシマ光源の実現が可能となる。 特に放電回路, 電極形状などを適当に選択する ことにより，真空紫外域において高効率動作す る疑似点光源が実現可能となり, リソグラ フィー用光源として注目される。

本論文では, パルスガスジェット放電により 励起された真空紫外キセノンエキシマ $\left(\mathrm{Xe}_{2}{ }^{*}\right)$ 光源(中心波長 $172 \mathrm{~nm}$ )の高出力, 高効率動作に ついて述べている。超音速パルスガスジェット によるキセノンクラスタの生成及びその定量的 な生成量の測定, ならびに異なる放電励起条件 における真空紫外発光の高性能化についての結 果を述べている。

\section{2. 希ガスクラスタの生成}

希ガスクラスタは超音速ジェット法により比 較的容易に生成される7)。数気圧の高気圧ガス を直径数百 $\mu \mathrm{m}$ のオリフィスから真空中に噴射 すると, 断熱膨張により $1 \mathrm{~K}$ 以下に冷却される。 これは希ガスクラスタの解離エネルギー $\left(\mathrm{Xe}_{2}\right.$ では281 K)より遥かに小さいため, 多体衝突に
より生成されたクラスタは解離されない。

エキシマの発光強度とクラス夕生成数との関 係を調べるために, 多光子イオン化飛行時間分 析法により超音速ジェット中のクラス夕密度を 測定した。希ガスクラスタをレーザー光でイオ ン化し, 電界による加速後, 一定距離はなれた イオン検出器で測定する。イオン化領域からイ オン検出器までの飛行時間は質量数の $1 / 2$ 乗に 比例するため, 質量数別のイオン数を検出器の 信号強度として測定することができる。

Fig. 1に実験装置を示す。実験装置は希ガス クラスタを生成する超音速ジェット用とクラス 夕の質量数別スペクトルを測定する飛行時間分 析用の $2 つ$ 真空チャンバから成る。超音速 ジェット用真空チャンバ内にはステンレス製コ ニカルノズル (口径 $0.3 \mathrm{~mm}$, 半值開口角 45 度) と自動車用燃料噴射装置を組み合わせた超音速 ジェット装置を取り付けている。希ガスは $4 \mathrm{~ms}$ の噴射時間のパルスジェットにより供給した。 この噴射時間は真空ポンプの容量により制限さ れている。希ガスはキセノンガスを用いた。 ズルから噴射されたキセノンガスジェットは

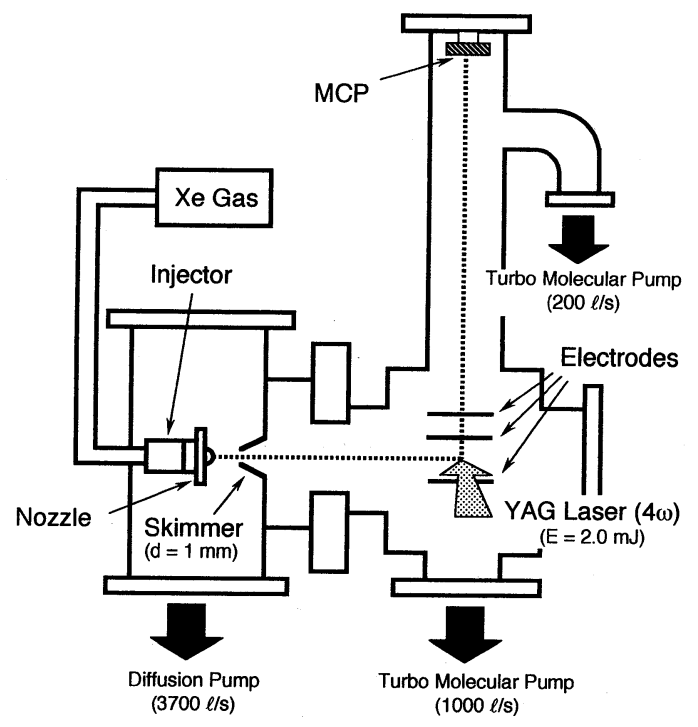

Fig. 1 Experimental apparatus for estimates of Xe cluster number densities. A vacuum chamber for the cluster production is connected to a time-of-flight mass spectrometer. 


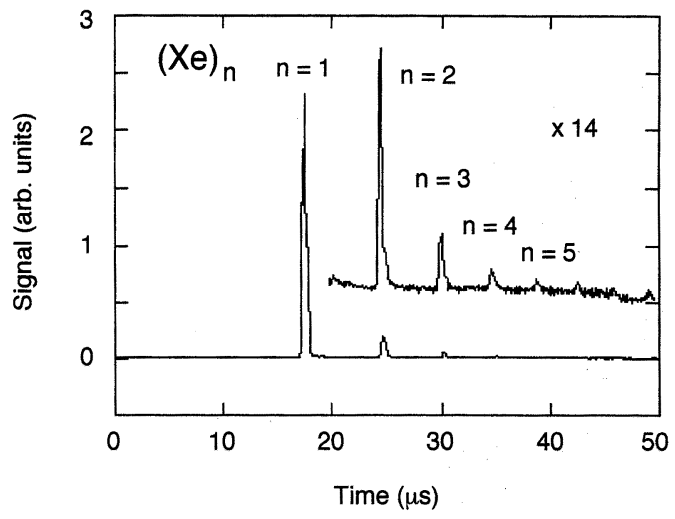

Fig. 2 Typical time-of-flight spectrum of Xe clusters observed.

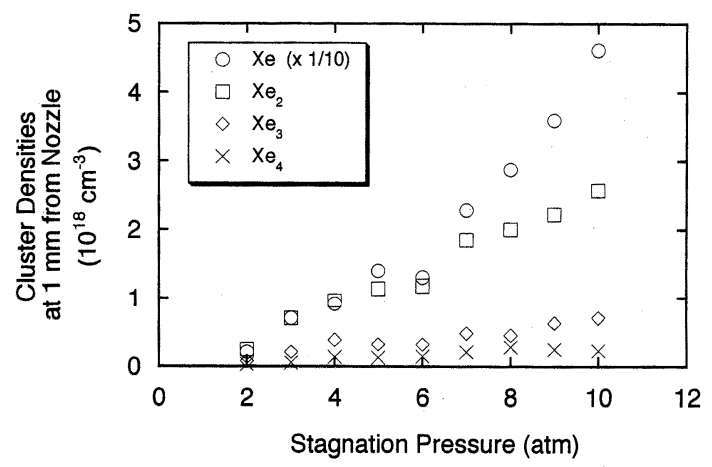

Fig. 3 Stagnation pressure dependence of the cluster densities at $1 \mathrm{~mm}$ from the nozzle.

$10 \mathrm{~mm}$ 下流のスキマー(口径 $1 \mathrm{~mm})$ を通して真 空度 $10^{-7}$ Torrの飛行時間分析用真空チャンバ内 (ジェット噴出時圧力 $10^{-5}$ Torr)に導入した。こ の真空チャンバの中心に設置してある電極間に おいて, キセノン原子及びクラスタはYAGレー ザーの4倍高調波 (波長 $266 \mathrm{~nm}$ ，エネルギー $2 \mathrm{~mJ})$ によって3光子電離し，イオン信号を飛行 管上部に設置したマイクロチャネルプレート (MCP)によって検出した。Fig. 2はMCPからの 信号強度の時間依存性である。横軸は飛行時間 で質量数に対応し，縦軸はイオン信号強度に比 例する。Fig. 2 より $n=8$ だのクラス夕が生成 し，その大部分は $\mathrm{Xe}_{2}$ であることが確認された。 キセノンガス背圧を変化させたときのノズル 下流 $1 \mathrm{~mm}$ におけるクラス夕密度をFig. 3 に示
す。既知の密度のキセノンをYAGレーザーに より電離したときにMCPに到達するイオン量 と, そのときの MCPの出力信号とを比較較正 することにより, クラス夕密度の絶対值を求め た。またノズル下流1 $\mathrm{mm}$ の地点での絶対密度 の換算には，超音速ジェットガス流の空間分布 を考慮した8)。クラスタの生成量は, キセノン 原子とともにキセノンガス背圧に比例して増加 していることがわかる。背圧10 atmにおいて， $\mathrm{Xe}$ の絶対密度は $4.6 \times 10^{19} \mathrm{~cm}^{-3}$ となり，ガスた め内の数密度 $3.0 \times 10^{20} \mathrm{~cm}^{-3}$ (常温)の数分の一 となった。また $\mathrm{Xe}_{2}$ の絶対密度は約 $10^{18} \mathrm{~cm}^{-3}$ のオーダーとなり，10\%程度の効率で $\mathrm{Xe}_{2}$ が 生成していることがわかった。

\section{3. パルスガスジェット放電励起希ガスエキ シマ発光}

2. で述べた超音速パルスジェットを用いて 生成したキセノンクラス夕を放電励起し，キセ ノンエキシマからの発光を観測した。このとき の実験装置図をFig. 4に示す。装置は，超音速 パルスガスジェット, それを内蔵する真空チャ ンバ，放電回路，及び発光の測定装置から成っ ている。真空チャンバ内部には，既述の希ガス 噴射用のインジェクター及び超音速ガスジェッ ト生成のためのステンレス製コニカルノズルを 設置し，このノズルをアノード電極として用い た。

2. で述べたように，超音速ジェットノズル を用いた場合，様々なサイズのクラスタが生成 される。また生成されるクラス夕は，分子線中 においてモノマーと異なる空間分布を持ってお り，より大きなサイズのクラス夕ほど分子線の 中心軸近傍に分布することがわかっている9。 この点に着目すると, ガス流の中心軸ほどクラ ス夕の励起が効率よく行なわれることが推測さ れる。そこで，カソード電極にはガス流を乱さ ないタングステン製の直径 $0.5 \mathrm{~mm}$ の針状電極 を使用した。

キセノンガス噴出はインジェクタを $0.5 \mathrm{~Hz}$ の 繰り返しで動作させることにより行った。この 


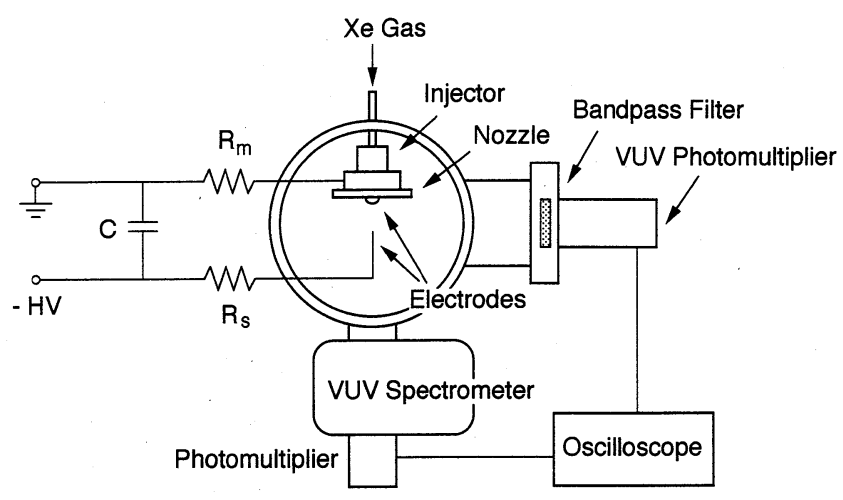

Fig. 4 Schematic of the experimental setup for a pulsed jet discharge.

繰り返し速度は排気ポンプの容量により制限さ れている。真空チャンバは, 油拡散ポンプによ りあらかじめ $10^{-5}$ Torr 程度に排気し，ガス噴 射中においても $10^{-2}$ Torr程度の真空度に保たれ ている。

最大出力電圧 $15 \mathrm{kV}$ のネントランスからの 出力を整流し, コンデンサ $C($ 容量 $0.53 \mu \mathrm{F})$ に 充電し電極間に印加した。パルス回路によりイ ンジェクターの開閉を制御し, 希ガスを噴出す ることによって電極間のインピーダンスが低下 し放電が開始する。電極間電圧は高電圧プロー ブにより，また，放電電流は回路中に挿入した 微小抵抗 $R_{\mathrm{m}}(300 \Omega)$ によって測定した。放電 電流の制御は, 安定化抵抗 $R_{\mathrm{s}}$ と充電電圧とを 変化させることによって行った。

放電部からの発光スペクトルは, 真空紫外分 光器を波長掃引することにより, シンチレータ 付きの光電子増倍管を用いて検出した。また, キセノンエキシマ発光の絶対出力測定には, 波 長較正されたバンドパスフィル夕(Acton社, 中心波長171.4 $\mathrm{nm}$, 半值幅 $11.5 \mathrm{~nm}$ )ならびに波 長感度較正された真空紫外用光電子増倍管(浜 松ホトニクス社，R972)を用いた。立体角の見 積もりの際, 発光体は点光源として取り扱った。

Fig. 5 に背圧 $10 \mathrm{~atm}$ ときに測定したスペク トルを示す。ここではスペクトル強度の相対的 な感度較正はされていない。波長 $135 \mathrm{~nm}$ から $235 \mathrm{~nm}$ の間で観測されたピークは, 中心波長

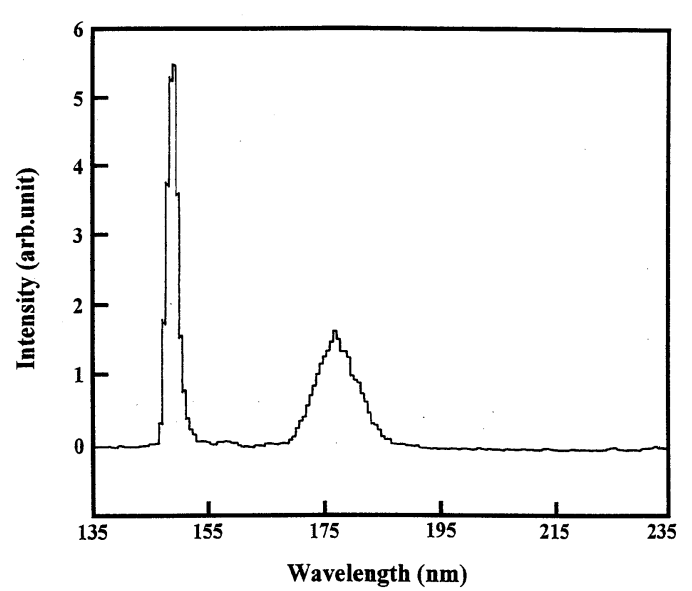

Fig. 5 Spectrum observed in a pulsed Xe jet discharge at a stagnation pressure of $10 \mathrm{~atm}$.

$176 \mathrm{~nm}$ のキセノンエキシマ及びキセノン原子 の共鳴線(波長147 nm)のみであった。

電極間隔 $3 \mathrm{~mm}$ の場合の電極間電圧(a), 放電 電流(b), キセノンエキシマの発光強度(c)の典 型的な時間波形をFig. 6に示す。電極間電圧は 放電開始と同時に降下し，それと同時に放電電 流が流れ始め約 $6 \mathrm{~ms}$ 持続する。この時間は本実 験で用いたパルスガスジェットのガス噴出時間 とほほ一致している。放電部への入力はこの電 圧降下值及び電流值より求めた。キセノンエキ シマの発光は放電電流に準じており, パルス幅 約 $5 \mathrm{~ms}$ の非常に長い発光が観測された。

電極間距離の違いによる発光強度の背圧依存 

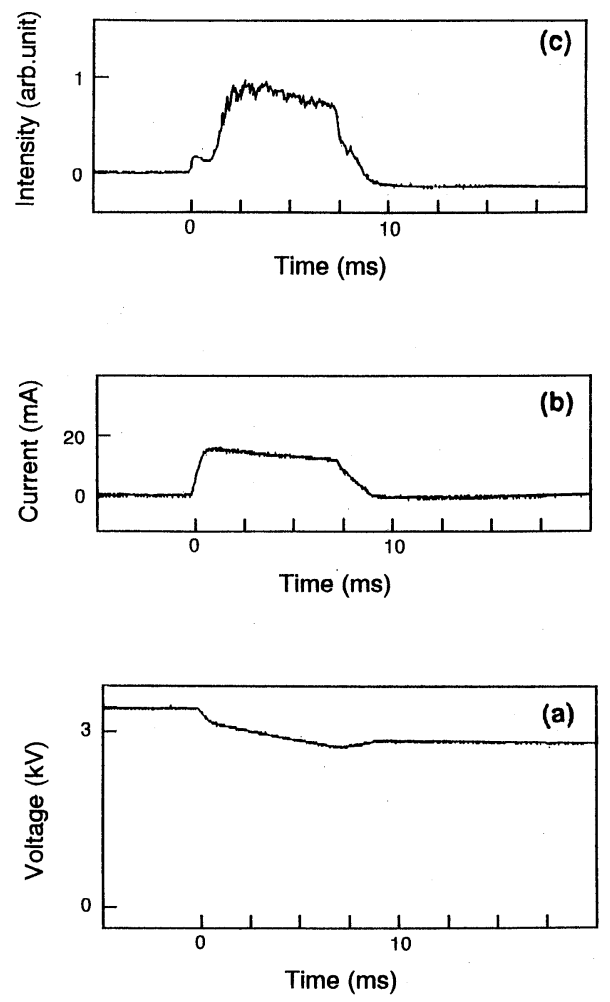

Fig. 6 Typical voltage and current waveforms at an electrode distance of $3 \mathrm{~mm}$, and a temporal waveform of $\mathrm{Xe}_{2}$ excimer emission. The excimer emission follows the current pulse and lasts $5 \mathrm{~ms}$ (FWHM).

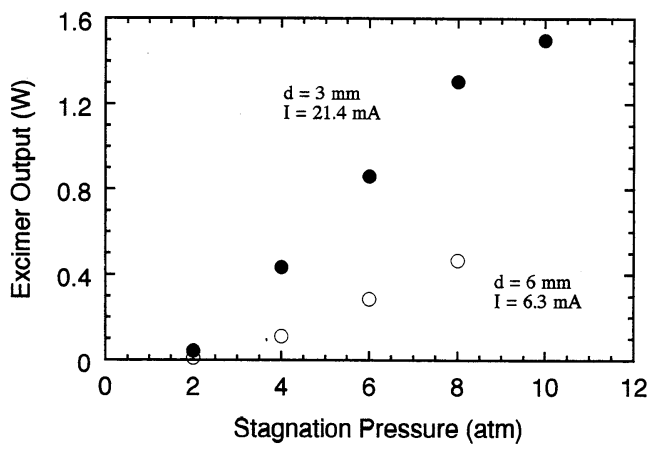

Fig. 7 Stagnation pressure dependence of $\mathrm{Xe}_{2}$ excimer output power at two electrode distances $(d=3$ and $6 \mathrm{~mm})$.

性をFig. 7に示す。電流值は各電極間隔におけ る最適值である。どちらの電極間隔においても
発光強度はノズルの背圧に比例して増加した。 電極間隔が $3 \mathrm{~mm}$ の場合は最適電流值が約3倍に 増加した。これは, 電極間隔 $6 \mathrm{~mm}$ の場合と比 べて, 高圧力下においても電極間以外での放電 が抑制され，安定な放電が得られたことによる。 電極間隔の減少に伴い励起密度も増加し, 発光 強度も増加した。電極間隔 $3 \mathrm{~mm}$ の場合, 背圧 $10 \mathrm{~atm}$ において出力 $1.5 \mathrm{~W} か ゙$ 得られた。このと きの効率は3.0\%に相当する。

\section{4. 検討}

Fig. 6のスペクトルから求めた中心波長 $176 \mathrm{~nm}$ のキセノンエキシマ光のバンド幅は 8.3 $\mathrm{nm}$ (半值)であった。この值は電子ビーム励起 の場合の值 $\left(12 \mathrm{~nm}^{10)}\right)$ と比べて著しく小さく, キセノンエキシマの低い振動温度 $\left(\right.$ 約 $250 \mathrm{~K}^{11)}$ ) が反映されている。この放電においては，ピー ク電流值 $\mathrm{mA}$ 程度が5 $\mathrm{ms}$ 持続することから安 定なグロー放電が得られていると考えられる。 このときの電流密度は最も大きい場合でも数十 $\mathrm{Acm}^{-2}$ 程度であり, 電極材料に起因するスペク トルあるいはキセノンイオンのスペクトルは観 測されなかったことから電極材料の放電による スパッタリングの影響はなく，また電子温度も 平均数 $\mathrm{V}$ 程度であると推測される。

Fig. 7の結果をFig. 3の結果と比較すると, キ セノンエキシマの発光はキセノンクラスタ生成 数に比例していることがわかる。他の形状の） ズル(ラバルノズル)を用いた場合でもクラスタ 量の背圧依存性とエキシマ光強度の背圧依存性 との間に強い相関があることが実験的に確認さ れている ${ }^{12)}$ 。これらの結果はクラス夕の直接 励起によるエキシマの生成機構を強く支持して いるものと考えられる。

観測されたスペクトル(Fig. 5)よりエキシマ の生成には, 準安定状態のキセノン原子が強く 関与していることがわかる。準直流グロー放電 中での電子温度を数 $\mathrm{eV}$ とすると, 電子による クラスタの直接励起に比して，キセノン原子の 準安定状態を介したエキシマの生成機構が優勢 であると考えられる。そこでエキシマ生成機構 
として, 準安定状態のキセノン原子による通常 の三体衝突生成反応とこれによるクラスタへの エネルギー移乗反応とを考えると，キセノンエ キシマとキセノン共鳴線との強度比は定常状態 では次のように表される。(Xe*6S [3/2 $]_{1}^{0}$ と6 $[3 / 2]_{2}^{0}$ (準安定状態)の数密度は等しいと仮定し ている。またジェットによる媒質の供給により 共鳴線の再吸収は無いと仮定している。)

$$
\frac{I\left(X \mathrm{e}_{2}^{*}\right)}{I\left(X \mathrm{e}^{*}\right)} \propto k_{1}[\mathrm{Xe}]^{2}+k_{2}\left[\mathrm{Xe}_{2}\right]
$$

ここで, $I\left(X_{\mathrm{e}_{2}}^{*}\right) / I\left(X \mathrm{e}^{*}\right)$ は, 実験より求めた エキシマと共鳴線との強度比であり， $k_{1}, k_{2}$ はそれぞれエキシマ生成の三体反応速度定数, クラス夕と準安定状態原子との反応速度定数で ある。Fig. 8は縦軸にこの強度比を, 横軸に背 圧をプロットしたものである。強度比は背圧に 比例して増加していることがわかる。横軸の背 圧は $[\mathrm{Xe}]$ に比例しており，さらにFig. 3 より， $\left[\mathrm{Xe}_{2}\right]$ に比例していることがわかる。この結果 から，エキシマ生成には，準安定状態によるク ラスタの直接励起が支配的で, 三体衝突を介し たエキシマ励起への寄与は無視できることがわ かる。

パルスジェットではノズル噴射後のガス密度 は，背圧から見積られるガス密度と同じではな いことがFig.3よりわかった。本実験における 三体衝突によるキセノンエキシマの生成率は,

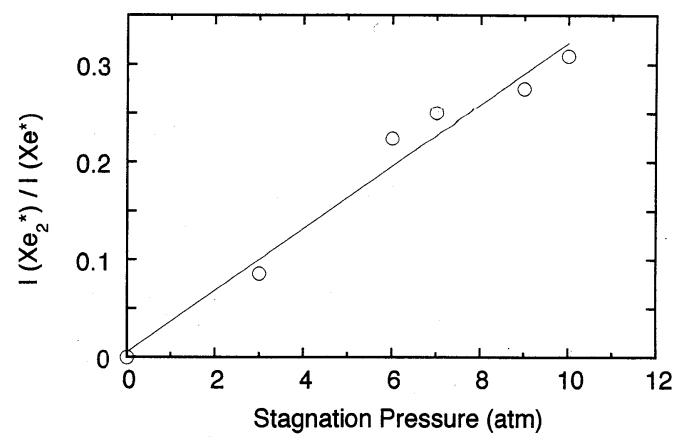

Fig. 8 Intensity ratio of $\mathrm{Xe}_{2}$ excimer and Xe resonance line as a function of the stagnation pressure. The ratio is proportional to the stagnation pressure. $k_{1}=10^{-32} \mathrm{~cm}^{6} \mathrm{~s}^{-113)}$ を用いると背圧 $10 \mathrm{~atm}$ にお いて約 $10^{6} \mathrm{~s}^{-1}$ である。一方，キセノン準安定状 態からのクラス夕の生成率は同じ圧力で $10^{8} \mathrm{~s}^{-1}$ 程度 $\left(k_{2}=10^{-10} \mathrm{~cm}^{3} \mathrm{~s}^{-1}\right.$ を用いた $\left.{ }^{14)}\right)$ とより高い 生成率となっていることがわかる。

放電電極間距離を減少させた場合のエキシマ 発光強度の増加は, 励起密度の増加に加えて, 超音速流がターミナルマッハ数に達する位置, すなわちクラスタの成長が完了しその密度が最 も高い位置に電極を配置したことの影響も考え られる。Fig. 7に示しているように，ノズルの 背圧 $10 \mathrm{~atm}$ において絶対出力を見積ったとこ ろ, 波長 $172 \mathrm{~nm}$ において最高出力 $1.5 \mathrm{~W}$ となり, そのときの効率は $3.0 \%$ \%あった。またこの值 から見積られるキセノンエキシマ密度は約 $10^{15}$ $\sim 10^{16} \mathrm{~cm}^{-3}$ であった。(放電体積の見積もりに より1オーダー程度不確定である)生成されてい るクラス夕の密度が電極の位置において約 $10^{18}$ $\mathrm{cm}^{-3}$ のオーダーであることを考えると, 非常 に効率のよいエキシマ生成が実現していること がわかった。

本実験で用いた準直流放電においては，放電 開始時よりグロー放電が実現でき, 効率よいエ キシマ生成が可能となったと考えられる。パル スガスジェット放電中では，クラス夕の直接励 起電子によるクラスタの直接励起に加えて, 長 寿命のキセノン原子の準安定状態とクラスタと の衝突によるエキシマの生成機構が共存してい ると考えられる。また予想どおり通常のエキシ マ生成反応である三体衝突反応は無視できるこ とがわかった。さらに，グロー放電中では生成 したクラスタのフラグメンテーションも抑制さ れる。発光のパルス幅はガスジェットの噴出時 間に準じていることから，排気容量の改善によ り，ガス噴出時間を増加させることが可能とな り,より長パルス化も可能である。

\section{5. まとめ}

コニカルノズルを用いたパルスガスジェット 放電により, 高出力, 高効率の真空紫外キセ, ンエキシマ光源を開発した。中心波長 $176 \mathrm{~nm}$ 
において, 最高出力は $1.5 \mathrm{~W}$, 効率 $3.0 \%$ あ゙り, 種々の応用に適用できる優れた特性を有してい

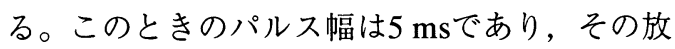
電形状は電極間隔できまる疑似点光源である。 これらのパルス幅及び発光形状は放電条件など の改善により可変とすることが期待できる。こ こではキセノンエキシマ発光特性についてのみ 述べたが，この方法は他の2種類の希ガスエキ シマにも適用可能であることから, 真空紫外域 において3種類の波長の異なる実用的な高性能 光源が実現する可能性がある。

\section{参 考 文 献}

1）熊谷寛, 陸太進, 豊田浩一：レーザー研究 19 (1991) 1073.

2) 佐々木亘：レーザー研究 13 (1985) 912.

3) T. Efthimiopoulos, B. P. Stoicheff and R. I. Thompson: Opt. Lett. 14 (1989) 624.

4) H. Phillips, S. Kubodera, R. Sauerbrey, F. K.
Tittel and P. J. Wisoff: IEEE J. Quantum Electron. 27 (1991) 95.

5) J. E. Tucker, M. F. Masters, B. L. Wexler and S. K. Searles: Opt. Lett. 17 (1992) 288.

6) W. Sasaki, K. Kurosawa and S. Matsuzono: Technical Digest of Conference of Lasers and Electro-Optics (CLEO), 12 (1992) 112.

7) 例えば, S. Sugano: "Rare Gas Clusters" in Microcluster Physics (Springer-Verlag, New York, 1991).

8) 手島光司：真空 30 (1987) 5 .

9) 正畠宏祐，篠原久典：分子線技術 38 (1990) 187.

10) P. W. Hoff, J. C. Swingle and C. K. Rhodes: Appl. Phys. Lett. 23 (1973) 245.

11) P. Dubé, T. Efhimiopoulos, M. J. Kiik and B. P. Stoicheff: Opt. Lett. 16 (1991) 1887.

12) K. Mitsuhashi and W. Sasaki (unpublished).

13) D. C. Lorents: Physica 82C (1976) 19.

14) S. K. Searles, J. E. Tucker, B. L. Wexler and M. F. Masters: IEEE J. Quantum Electron. 30 (1994) 2141. 